NASA/TM-2000-209891, Vol. 56

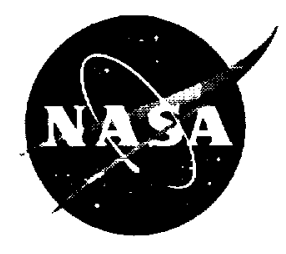

Technical Report Series on the Boreal Ecosystem-Atmosphere Study (BOREAS)

Forrest G. Hall and Jaime Nickeson, Editors

\title{
Volume 56
}

BOREAS RSS-8 Snow Maps Derived from Landsat TM Imagery

D. Hall, A. Chang, J. Foster, and J.Y.L. Chien

National Aeronautics and

Space Administration

Goddard Space Flight Center

Greenbelt, Maryland 20771 
The NASA STI Program Office ... in Profile

Since its founding, NASA has been dedicated to the advancement of aeronautics and space science. The NASA Scientific and Technical Information (STI) Program Office plays a key part in helping NASA maintain this important role.

The NASA STI Program Office is operated by Langley Research Center, the lead center for NASA's scientific and technical information. The NASA STI Program Office provides access to the NASA STI Database, the largest collection of aeronautical and space science STI in the world. The Program Office is also NASA's institutional mechanism for disseminating the results of its research and development activities. These results are published by NASA in the NASA STI Report Series, which includes the following report types:

- TECHNICAL PUBLICATION. Reports of completed research or a major significant phase of research that present the results of NASA programs and include extensive data or theoretical analysis. Includes compilations of significant scientific and technical data and information deemed to be of continuing reference value. NASA's counterpart of peer-reviewed formal professional papers but has less stringent limitations on manuscript length and extent of graphic presentations.

- TECHNICAL MEMORANDUM. Scientific and technical findings that are preliminary or of specialized interest, e.g., quick release reports, working papers, and bibliographies that contain minimal annotation. Does not contain extensive analysis.

- CONTRACTOR REPORT. Scientific and technical findings by NASA-sponsored contractors and grantees.
- CONFERENCE PUBLICATION. Collected papers from scientific and technical conferences, symposia, seminars, or other meetings sponsored or cosponsored by NASA.

- SPECIAL PUBLICATION. Scientific, technical, or historical information from NASA programs, projects, and mission, often concerned with subjects having substantial public interest.

- TECHNICAL TRANSLATION. English-language translations of foreign scientific and technical material pertinent to NASA's mission.

Specialized services that complement the STI Program Office's diverse offerings include creating custom thesauri, building customized databases, organizing and publishing research results ... even providing videos.

For more information about the NASA STI Program Office, see the following:

- Access the NASA STI Program Home Page at http://www.sti.nasa.gov/STI-homepage.html

- E-mail your question via the Internet to help@sti.nasa.gov

- Fax your question to the NASA Access Help Desk at (301) 621-0134

- Telephone the NASA Access Help Desk at (301) 621-0390

- Write to:

NASA Access Help Desk NASA Center for AeroSpace Information 7121 Standard Drive

Hanover, MD 21076-1320 
NASA/TM-2000-209891, Vol. 56

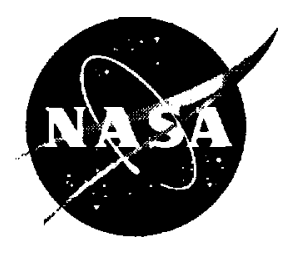

\section{Technical Report Series on the Boreal Ecosystem-Atmosphere Study (BOREAS)}

Forrest G. Hall and Jaime Nickeson, Editors

\section{Volume 56 \\ BOREAS RSS-8 Snow Maps Derived from Landsat TM Imagery}

Dorothy Hall, Al Chang, and Jim Foster, Goddard Space Flight Center, Greenbelt, Maryland Janet Y.L. Chien, GSC

National Aeronautics and

Space Administration

Goddard Space Flight Center

Greenbelt, Maryland 20771 


\section{Available from:}

NASA Center for AeroSpace Information 7121 Standard Drive

Hanover, MD 21076-1320

Price Code: A17
National Technical Information Service 5285 Port Royal Road Springfield, VA 22161

Price Code: A10 


\title{
BOREAS RSS-8 Snow Maps Derived from Landsat TM Imagery
}

\author{
Dorothy K. Hall, Alfred T.C. Chang, James L. Foster, Janet Y.L. Chien
}

\section{Summary}

The BOREAS RSS-8 team utilized Landsat TM images to perform mapping of snow extent over the SSA. This data set consists of two Landsat TM images that were used to determine the snow-covered pixels over the BOREAS SSA on 18-Jan-1993 and on 06-Feb-1994. The data are stored in binary image format files.

Note that some of the data files on the BOREAS CD-ROMs have been compressed using the Gzip program. See Section 8.2 for details.

\section{Table of Contents}

1) Data Set Overview

2) Investigator(s)

3) Theory of Measurements

4) Equipment

5) Data Acquisition Methods

6) Observations

7) Data Description

8) Data Organization

9) Data Manipulations

10) Errors

11) Notes

12) Application of the Data Set

13) Future Modifications and Plans

14) Software

15) Data Access

16) Output Products and Availability

17) References

18) Glossary of Terms

19) List of Acronyms

20) Document Information

\section{Data Set Overview}

\subsection{Data Set Identification \\ BOREAS RSS-08 Snow Maps Derived from Landsat TM Imagery}

\subsection{Data Set Introduction}

The Landsat Thematic Mapper (TM) sensor was used to create maps of snow-covered pixels within two winter scenes acquired over the BOReal Ecosystem-Atmosphere Study (BOREAS) Southern Study Area (SSA) in 1993 and 1994. An automated technique for detecting snow-covered pixels using TM image-band ratios and reflectance thresholds was used.

\subsection{Objective/Purpose}

The objective of obtaining this data set was to use an automated technique to map snow in the BOREAS SSA. The algorithm selected to do this, called SNOMAP, has been developed to map snow using future Earth Observing System (EOS) Moderate-Resolution Imaging Spectroradiometer (MODIS) data. A secondary objective was to compare the results of snow mapping using the Landsat 
TM and MODIS Airborne Simulator (MAS) sensors in order to determine the relative accuracy of the snow maps. However, very little MAS data were available for comparison.

Although the Landsat TM sensor can be used as a prototype for the MODIS sensor, it is not ideal as a prototype for MODIS because it does not have the same spectral bands as MODIS and its Field-Of-View (FOV) angle is only $\pm 8^{\circ}$, while that of the MODIS sensor is $\pm 55^{\circ}$. Nevertheless, until receipt of significant MAS data, the TM was the most appropriate prototype sensor available for developing a snow-mapping algorithm for MODIS.

For investigators who are using snow maps in their modeling efforts, the SNOMAP-derived snow maps may be useful.

\subsection{Summary of Parameters}

Snow in the TM scene and in the BOREAS SSA test site is the parameter of interest.

\subsection{Discussion}

The experiment was conducted in order to determine the accuracy of snow mapping using the MODIS snow-mapping algorithm, SNOMAP, in different forest types; specifically, deciduous and coniferous forests. Field measurements were acquired simultaneously with the Landsat TM test data. In addition, a National Aeronautics and Space Administration (NASA) ER-2 overflight was flown on 08-Feb-1994. MAS data were acquired using the MAS when it had only seven spectral bands available; only two scenes of MAS data were acquired, and clouds contaminated one of the scenes.

\subsection{Related Data Sets}

BOREAS HYD-02 Estimated Snow Water Equivalent (SWE) from Microwave

BOREAS Level-2 MAS Imagery: Reflectance and Temperatures in BSQ Format

BOREAS Level-3a Landsat TM Imagery: Scaled At-sensor Radiance in BSQ Format

\section{Investigator(s)}

\subsection{Investigator(s) Names and Title}

Principal Investigator:

Dorothy K. Hall Scientist

Co-Investigators:

Alfred T. C. Chang Scientist

James L. Foster Scientist

\subsection{Title of Investigation}

Automated Snow Mapping in the Southern BOREAS Test Site

\subsection{Contact Information}

\section{Contact 1:}

Dorothy K. Hall

Hydrological Sciences Branch

Code 974

NASA GSFC

Greenbelt, MD 20771

(301) 286-6892

(301) 286-1758 (fax)

Dorothy.K.Hall@gsfc.nasa.gov 


\author{
Contact 2: \\ Alfred T.C. Chang \\ Hydrological Sciences Branch \\ Code 974 \\ NASA GSFC \\ Greenbelt, MD 20771 \\ (301) 286-8997 \\ (301) 286-1758 (fax) \\ Alfred.T.Chang@gsfc.nasa.gov \\ Contact 3: \\ James L. Foster \\ Hydrological Sciences Branch \\ Code 974 \\ NASA GSFC \\ Greenbelt, MD 20771 \\ (301) 286-7096 \\ (301) 286-1758 (fax) \\ James.L.Foster@gsfc.nasa.gov

\section{Contact 4:} \\ Jaime Nickeson \\ Raytheon ITSS \\ NASA GSFC \\ Code 923 \\ Greenbelt, MD 20771 \\ (301) 286-3373 \\ (301) 286-0239 (fax) \\ Jaime.Nickeson@gsfc.nasa.gov
}

\title{
3. Theory of Measurements
}

The normalized-difference snow index (NDSI) is useful for the identification of snow and ice and for separating snow/ice and most cumulus clouds to improve identification of snow/ice and decrease reliance on single-band, "universal" thresholds. The NDSI is a measure of the relative magnitude of the characteristic reflectance difference between the visible and short-wave infrared (IR) reflectance of snow. The NDSI is insensitive to a wide range of illumination conditions, is partially normalized for atmospheric effects, and does not depend on reflectance in a single band. The NDSI is analogous to the normalized-difference vegetation index (NDVI). Various other techniques employing band ratio techniques have been used previously to map snow, as discussed in Section 1. For Landsat TM data, the NDSI is calculated as:

$$
\text { NDSI }=(\text { TM Band } 2-\text { TM Band 5) } /(\text { TM Band } 2+\text { TM Band 5) }
$$

Pixels with $50 \%$ or greater snow coverage have been found to have NDSI values greater than or equal to 0.4 . Separation of snow and water is done by a TM band 4 reflectance test. If the reflectance of TM band 4 is greater than $11 \%$, and the NDSI is greater than or equal to 0.40 , snow covers $50 \%$ or more of the pixel. The NDSI threshold has been determined from detailed analysis of numerous TM scenes and comparisons with supervised-classification techniques. 


\section{Equipment}

\subsection{Sensor/Instrument Description}

The TM sensor system records radiation from seven bands in the electromagnetic spectrum. It has a telescope that directs the incoming radiant flux obtained along a scan line through a scan line collector to the visible and near-infrared focal plane, or to the mid-infrared and thermal-infrared cooled focal plane. The detectors for the visible and near-infrared bands (1 to 4 ) are four staggered linear arrays, each containing 16 silicon detectors. The two mid-infrared detectors are 16 indium-antimonide cells in a staggered linear array, and the thermal-infrared detector is a four-element array of mercury-cadmium-telluride cells. The spectral regions, band widths, and primary use of each channel are given in the following table:

\begin{tabular}{|c|c|c|c|}
\hline Channel & Wavele & ength $(\mu \mathrm{m})$ & Primary Use \\
\hline -ー-ーー-ー & ------ & --------- & 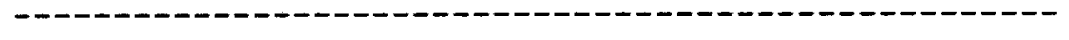 \\
\hline 1 & 0.451 & 0.521 & $\begin{array}{l}\text { Coastal water mapping, soil vegetation } \\
\text { differentiation, deciduous/coniferous } \\
\text { differentiation. }\end{array}$ \\
\hline 2 & 0.526 & 0.615 & Green reflectance by healthy vegetation. \\
\hline 3 & 0.622 & 0.699 & $\begin{array}{l}\text { Chlorophyll absorption for plant species } \\
\text { differentiation. }\end{array}$ \\
\hline 4 & 0.771 & 0.905 & Biomass surveys, water body delineation. \\
\hline 5 & 1.564 & 1.790 & $\begin{array}{l}\text { Vegetation moisture measurement, snow cloud } \\
\text { differentiation. }\end{array}$ \\
\hline 6 & 10.450 & -12.46 & Plant heat stress measurement, other thermal mapping. \\
\hline 7 & 2.083 & -2.351 & Hydrothermal mapping. \\
\hline
\end{tabular}

\subsubsection{Collection Environment}

Data were collected on 06-Feb-1994 when the temperatures were very cold (approximately $-20^{\circ} \mathrm{F}$ ). There was generally some cloud cover. The ground was continuously snow covered except for tree branches, stems, and canopies. Coniferous tree canopies were typically snow free, although there was some snow in the canopies. No ground measurements were available for the January 1993 scene.

The BOREAS Landsat TM level-3s and -3p images were acquired through the Canada Centre for Remote Sensing (CCRS). Radiometric corrections and systematic geometric corrections are applied to produce the images in a path-oriented, systematically corrected (level-3s) or precision-corrected (level-3p) form. A full TM image contains 6,920 pixels in each of 5,728 lines. Before any geometric corrections, the ground resolution is $30 \mathrm{~m}$ for bands $1,2,3,4,5$, and 7 and $120 \mathrm{~m}$ for band 6 at nadir. The pixel values of the images can range from 0 to 255 . This allows each pixel to be stored in a single byte field. The level-3s and level-3p images were processed through the CCRS Geocoded Image Correction System (GICS).

\subsubsection{Source/Platform}

Landsat 4 and/or 5 .

\subsubsection{Source/Platform Mission Objectives}

The Landsat TM is designed to respond to and measure both reflected and emitted Earth surface radiation to enable the investigation, survey, inventory, and mapping of Earth's natural resources.

\subsubsection{Key Variables}

Reflected radiation, emitted radiation, temperature.

\subsubsection{Principles of Operation}

The TM is a scanning optical sensor operating in the visible and infrared wavelengths. It contains a scan mirror assembly that directly projects the reflected Earth radiation onto detectors arrayed in two focal planes. The TM achieves better image resolution, sharper color separation, and greater in-flight 
geometric and radiometric accuracy for seven spectral bands simultaneously than the previous generation sensor, the Multi-Spectral Scanner (MSS). Data collected by the sensor are beamed back to ground receiving stations for processing.

\subsubsection{Sensor/Instrument Measurement Geometry}

The TM sensor depends on the forward motion of the spacecraft for the along-track scan and uses a moving mirror assembly to scan in the cross-track direction (perpendicular to the spacecraft). The instantaneous field-of-view (IFOV) for each detector from bands 1-5 and band 7 is equivalent to a $30-\mathrm{m}$ square when projected to the ground at nadir; band 6 (the thermal-infrared band) has an IFOV equivalent to a $120-\mathrm{m}$ square at nadir.

\subsubsection{Manufacturer of Sensor/Instrument NASA GSFC \\ Greenbelt, MD 20771 \\ Hughes Aircraft Company \\ Santa Barbara Remote Sensing (SBRS) \\ 75 Coromar Drive \\ Goleta, CA 93117}

\subsection{Calibration}

The intemal calibrator, a flex-pivot-mounted shutter assembly, is synchronized with the scan mirror, oscillating at the same $7-\mathrm{Hz}$ frequency. During the turnaround period of the scan mirror, the shutter introduces the calibration source energy and a black direct-current restoration surface into the 100 detector FOV. The calibration signals for bands 1-5 and band 7 are derived from three regulated tungsten-filament lamps.

The calibration source for band 6 is a blackbody with three temperature selections, commanded from the ground. The method for transmitting radiation to the moving calibration shutter allows the tungsten lamps to provide radiation independently and to contribute proportionately to the illumination of all detectors.

\subsubsection{Specifications}

\begin{tabular}{lc} 
& Radiometric \\
Band & Sensitivity [NE (dP)] \\
\hline 1 & $0.8 \%$ \\
2 & $0.5 \%$ \\
3 & $0.5 \%$ \\
4 & $0.5 \%$ \\
5 & $1.0 \%$ \\
6 & $0.5 \mathrm{~K}[\mathrm{NE}(\mathrm{dT})]$ \\
7 & $2.4 \%$ \\
Ground IFov & $30 \mathrm{~m} \mathrm{(Bands} \mathrm{1-5,} \mathrm{7)}$ \\
& $120 \mathrm{~m} \mathrm{(Band} \mathrm{6)}$ \\
Avg. altitude & $699.6 \mathrm{~km}$ \\
Data rate & $85 \mathrm{Mbps}$ \\
Quantization levels & 256 \\
Orbit angle & $8.15^{\circ}$ \\
Orbital nodal Period & $98.88 \mathrm{minutes}$ \\
Scan width & $185 \mathrm{~km}$ \\
Scan angle & $14.9^{\circ}$ \\
Image overlap & $7.6 \%$
\end{tabular}


Note: The radiometric sensitivities are the noise-equivalent (NE) reflectance differences for the reflective channels expressed as percentages [NE(dP)], and temperature differences for the thermal-infrared bands [NE(dT)] in Kelvin.

\subsubsection{Tolerance}

The TM channels were designed for an NE differential represented by the radiometric sensitivity shown in Section 4.2.1.

\subsubsection{Frequency of Calibration}

The absolute radiometric calibration between bands on the TM sensor is maintained by using internal calibrators that are physically located between the telescope and the detectors and are sampled at the end of a scan.

\subsubsection{Other Calibration Information}

Relative within-band radiometric calibration, to reduce "striping," is provided by a scene-based procedure called histogram equalization. The absolute accuracy and relative precision of this calibration scheme assumes that any changes in the optics of the primary telescope or the "effective radiance" from the internal calibrator lamps are insignificant in comparison to the changes in detector sensitivity and electronic gain and bias with time, and that the scene-dependent sampling is sufficiently precise for the required within-scan destriping from histogram equalization.

Each TM reflective band and the internal calibrator lamps were calibrated prior to launch using lamps in integrating spheres that in tum were calibrated against lamps traceable to calibrated National Bureau of Standards lamps. The absolute radiometric calibration constants in the "short-term" and "long-term" parameter files used for ground processing were modified after launch only when inconsistency existed within or between bands, changes occurred in the inherent dynamic range of the sensors, or it was desirable to make quantized and calibrated values from one sensor match those from another.

\section{Data Acquisition Methods}

The BOREAS Landsat TM level-3s and $-3 p$ images were acquired through the CCRS. Radiometric corrections and systematic or precision geometric corrections are applied to produce the images in a path-oriented form. A full TM image contains 6,920 pixels in each of 5,728 lines. Before any geometric corrections, the ground resolution is $30 \mathrm{~m}$ for bands $1-5$ and band 7 and $120 \mathrm{~m}$ for band 6 at nadir. The pixel values of the images can range from 0 to 255 . This allows each pixel to be stored in a single-byte field.

\section{Observations}

\subsection{Data Notes}

None.

\subsection{Field Notes}

During the Landsat TM overflight that occurred on 06-Feb-1994, a team of scientists was on the ground in Prince Albert National Park (PANP), Saskatchewan. Observations indicated that the ground was continuously snow covered except for tree stems, canopies, and trunks, which were largely snow free. Some snow, but not very much, was present on the coniferous tree canopy. 


\section{Data Description}

\subsection{Spatial Characteristics}

\subsubsection{Spatial Coverage}

The BOREAS level-3a Landsat TM images used for these products were World Reference System (WRS) path/row 37/22-23 and cover the entire SSA and more.

The North American Datum of 1983 (NAD83) corner coordinates of the SSA are:

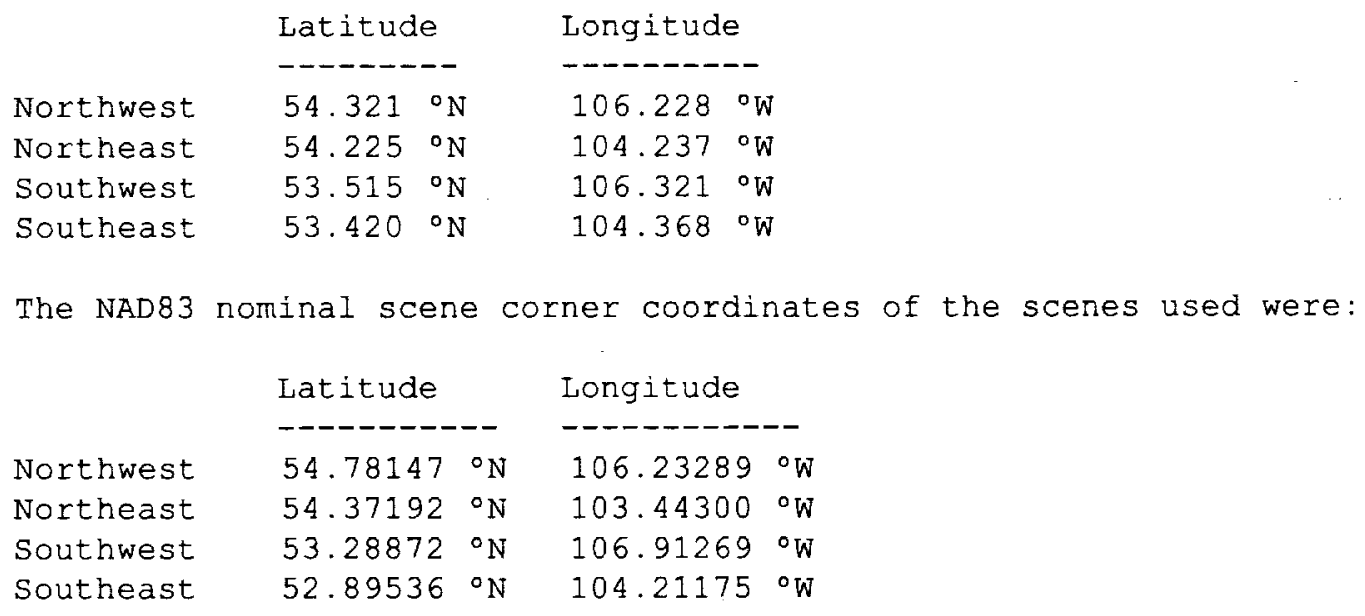

\subsubsection{Spatial Coverage Map}

Not available.

\subsubsection{Spatial Resolution}

The images derived here have the same spatial resolution as the Landsat TM level-3a product. The level-3s and $-3 \mathrm{p}$ Landsat TM images have had geometric corrections applied so that the spatial resolution for all pixels is $30 \mathrm{~m}$ in all bands.

\subsubsection{Projection}

The two TM scenes processed for this data set were registered to each other. The 06-Feb-1994 scene was used as the reference scene in this case. These products, like the level-3a Landsat TM image, are in a Universal Transverse Mercator (UTM) projection based on the NAD83.

\subsubsection{Grid Description}

The pixel/grid spacing for each pixel in these images is $30 \mathrm{~m}$ in the UTM projection.

\subsection{Temporal Characteristics}

\subsubsection{Temporal Coverage}

The data submitted are snow maps derived from the 18-Jan-1993 and 06-Feb-1994 TM scenes.

\subsubsection{Temporal Coverage Map}

Not available.

\subsubsection{Temporal Resolution}

Two Landsat TM winter scenes from 1993 and 1994 were selected to create these snow map products. 


\subsection{Data Characteristics}

\subsubsection{Parameter/Variable}

Snow cover.

\subsubsection{Variable Description/Definition}

A snow-covered pixel.

\subsubsection{Unit of Measurement}

Coded but unitless value.

\subsubsection{Data Source}

The level-3a Landsat TM images used to create the snow maps were supplied to BOREAS by CCRS.

\subsubsection{Data Range}

The derived map is binary. Each pixel is considered to be either snow covered or not snow covered. If a pixel is approximately 50\% snow covered, it will be mapped as snow. Snow-covered pixels are mapped to a Digital Number (DN) of 1 , all others are zero.

\subsection{Sample Data Record}

Not applicable to image data.

\section{Data Organization}

\subsection{Data Granularity}

The smallest unit of this data set tracked by the BOREAS Information System (BORIS) is each individual snow map image.

\subsection{Data Format(s)}

\subsubsection{Uncompressed Data Files}

Three files comprise the Landsat TM snow map product, one 80-byte American Standard Code for Information Interchange (ASCII) header file and two binary image files. The image files contain one image line per physical record. Each record has 6,930 bytes (image samples) of image data for each of 5,728 records (image lines) on tape. There are no header records in the image files.

\subsubsection{Compressed CD-ROM Files}

On the BOREAS CD-ROMs, the ASCII header file for this image is stored as ASCII text; however, the image files been compressed with the Gzip (GNU zip) compression program (file_name.gz). These data have been compressed using gzip version 1.2.4 and the high compression (-9) option (Copyright (C) 1992-1993 Jean-loup Gailly). Gzip uses the Lempel-Ziv algorithm (Welch, 1994) also used in the zip and PKZIP programs. The compressed files may be uncompressed using gzip (with the -d option) or gunzip. Gzip is available from many Web sites (for example, the ftp site prep.ai.mit.edu/pub/gnu/gzip-*.*) for a variety of operating systems in both executable and source code form. Versions of the decompression software for various systems are included on the CD-ROMs. 


\section{Data Manipulations}

\subsection{Formulae}

The following formula is used to map snow cover:

If $($ TM2-TM5)/(TM2+TM5) $>=0.4$, and RTM4 $>=11 \%$, then the pixel is snow covered.

TM2, TM4, and TM5 are Landsat TM bands 2, 4, and 5, respectively. RTM4 is reflectance of band 4.

\subsection{Data Processing Sequence}

\subsubsection{Processing Steps}

BORIS staff copied the ASCII and compressed the binary files for release on CD-ROM.

\subsubsection{Processing Changes \\ None.}

\subsection{Calculations}

\subsubsection{Special Corrections/Adjustments}

None.

\subsubsection{Calculated Variables}

The derived map is binary. Each pixel is considered to be either snow covered or not snow covered based on the formula in Section 9.1.

\subsection{Graphs and Plots}

None given.

\section{Errors}

\subsection{Sources of Error}

There may be errors caused by thin cloud cover being mapped as snow cover, particularly on the 06-Feb-1994 image. In addition, errors could exist where any ground cover was obscured by tree canopies, stems, and trunks.

\subsection{Quality Assessment}

\subsubsection{Data Validation by Source}

Data have not been validated.

\subsubsection{Confidence Level/Accuracy Judgment}

The level-3a TM image data used were of good quality. The quality of the snow maps, however, has not been ascertained.

\subsubsection{Measurement Error for Parameters}

Percentage of snow mapped in coniferous and deciduous forests has been calculated for the $06-F e b-1994$ scene. Approximately $72 \%$ of the coniferous forests were mapped as snow covered, while only $14 \%$ of the deciduous forests were mapped as snow covered. Though the snow was continuous, areas existed that did not have snow because of tree stems, branches, and trunks. It is not understood why more snow is mapped in the coniferous forests than in the deciduous forests; it may relate to grain-sized differences between scenes. 


\subsubsection{Additional Quality Assessments}

None given.

\subsubsection{Data Verification by Data Center}

None.

\section{Notes}

\subsection{Limitations of the Data}

Data are currently useful only for assessing the ability of the MODIS SNOMAP algorithm to map snow in different forest-cover types.

\subsection{Known Problems with the Data}

None.

\subsection{Usage Guidance}

Cirrus clouds obscure much of the 06-Feb-1994 scene.

Before uncompressing the Gzip files on CD-ROM, be sure that you have enough disk space to hold the uncompressed data files. Then use the appropriate decompression program provided on the CD-ROM for your specific system.

\subsection{Other Relevant Information \\ None.}

\section{Application of the Data Set}

So far, the data set has been used to show that the conventional wisdom that more snow will be mapped in deciduous forests than in coniferous forests is not always true. The opposite of this was found in the case of the 06-Feb-1994 TM image. However, there was no measurable difference in the amount of snow mapped between forest-cover type in the 18-Jan-1993 TM image.

\section{Future Modification and Plans}

The MODIS algorithm is being modified to map more snow in forests than is currently possible.

\section{Software}

\subsection{Software Description}

Software to calculate snow cover from Landsat TM data was developed in-house and is available upon request. Gzip (GNU zip) uses the Lempel-Ziv algorithm (Welch, 1994) used in the zip and PKZIP commands.

\subsection{Software Access}

Software to calculate snow cover from Landsat TM data can be obtained by contacting Dorothy Hall, Code 974, NASA GSFC, Dorothy.K.Hall@gsfc.nasa.gov. Gzip is available from many Web sites across the Internet (for example, FTP site prep.ai.mit.edu/pub/gnu/gzip-*.*) for a variety of operating systems in both executable and source code form. Versions of the decompression software for various systems are included on the CD-ROMs. 


\section{Data Access}

The RSS-08 snow map data are available from the Earth Observing System Data and Information System (EOSDIS) Oak Ridge National Laboratory (ORNL) Distributed Active Archive Center (DAAC).

\subsection{Contact Information}

For BOREAS data and documentation please contact:

ORNL DAAC User Services

Oak Ridge National Laboratory

P.O. Box 2008 MS-6407

Oak Ridge, TN 37831-6407

Phone: (423) 241-3952

Fax: (423) 574-4665

E-mail: ornldaac@ornl.gov or ornl@eos.nasa.gov

\subsection{Data Center Identification}

Earth Observing System Data and Information System (EOSDIS) Oak Ridge National Laboratory (ORNL) Distributed Active Archive Center (DAAC) for Biogeochemical Dynamics http://www-eosdis.ornl.gov/.

\subsection{Procedures for Obtaining Data}

Users may obtain data directly through the ORNL DAAC online search and order system [http://www-eosdis.ornl.gov/] and the anonymous FTP site [ftp://www-eosdis.ornl.gov/data/] or by contacting User Services by electronic mail, telephone, fax, letter, or personal visit using the contact information in Section 15.1.

\subsection{Data Center Status/Plans}

The ORNL DAAC is the primary source for BOREAS field measurement, image, GIS, and hardcopy data products. The BOREAS CD-ROM and data referenced or listed in inventories on the CD-ROM are available from the ORNL DAAC.

\section{Output Products and Availability}

\subsection{Tape Products}

The snow maps can be made available on 8-mm or Digital Archive Tape (DAT) media.

\subsection{Film Products}

None.

\subsection{Other Products}

These data are available on the BOREAS CD-ROM series. 


\section{References}

17.1 Platform/Sensor/Instrument/Data Processing Documentation

Welch, T.A. 1984. A Technique for High Performance Data Compression. IEEE Computer, Vol. 17, No. 6, pp. 8-19.

\subsection{Journal Articles and Study Reports}

Klein, A., D.K. Hall, and G.A. Riggs. 1998. Improving snow-cover mapping in forests through the use of a canopy reflectance model. Hydological Process 12: (10-11). 1723 - 1744. Aug-Sep 1998.

Newcomer, J., D. Landis, S. Conrad, S. Curd, K. Huemmrich, D. Knapp, A. Morrell, J. Nickeson, A. Papagno, D. Rinker, R. Strub, T. Twine, F. Hall, and P. Sellers, eds. 2000. Collected Data of The Boreal Ecosystem-Atmosphere Study. NASA. CD-ROM.

Sellers, P. and F. Hall. 1994. Boreal Ecosystem-Atmosphere Study: Experiment Plan. Version 1994-3.0, NASA BOREAS Report (EXPLAN 94).

Sellers, P. and F. Hall. 1996. Boreal Ecosystem-Atmosphere Study: Experiment Plan. Version 1996-2.0, NASA BOREAS Report (EXPLAN 96).

Sellers, P., F. Hall, and K.F. Huemmrich. 1996. Boreal Ecosystem-Atmosphere Study: 1994 Operations. NASA BOREAS Report (OPS DOC 94).

Sellers, P., F. Hall, and K.F. Huemmrich. 1997. Boreal Ecosystem-Atmosphere Study: 1996 Operations. NASA BOREAS Report (OPS DOC 96).

Sellers, P., F. Hall, H. Margolis, B. Kelly, D. Baldocchi, G. den Hartog, J. Cihlar, M.G. Ryan, B. Goodison, P. Crill, K.J. Ranson, D. Lettenmaier, and D.E. Wickland. 1995. The boreal ecosystem-atmosphere study (BOREAS): an overview and early results from the 1994 field year. Bulletin of the American Meteorological Society. 76(9):1549-1577.

Sellers, P.J., F.G. Hall, R.D. Kelly, A. Black, D. Baldocchi, J. Berry, M. Ryan, K.J. Ranson, P.M. Crill, D.P. Lettenmaier, H. Margolis, J. Cihlar, J. Newcomer, D. Fitzjarrald, P.G. Jarvis, S.T. Gower, D. Halliwell, D. Williams, B. Goodison, D.E. Wickland, and F.E. Guertin. 1997. BOREAS in 1997: Experiment Overview, Scientific Results and Future Directions. Joumal of Geophysical Research 102(D24): 28,731-28,770.

\subsection{Archive/DBMS Usage Documentation None.}

\section{Glossary of Terms}

None. 


\section{List of Acronyms}

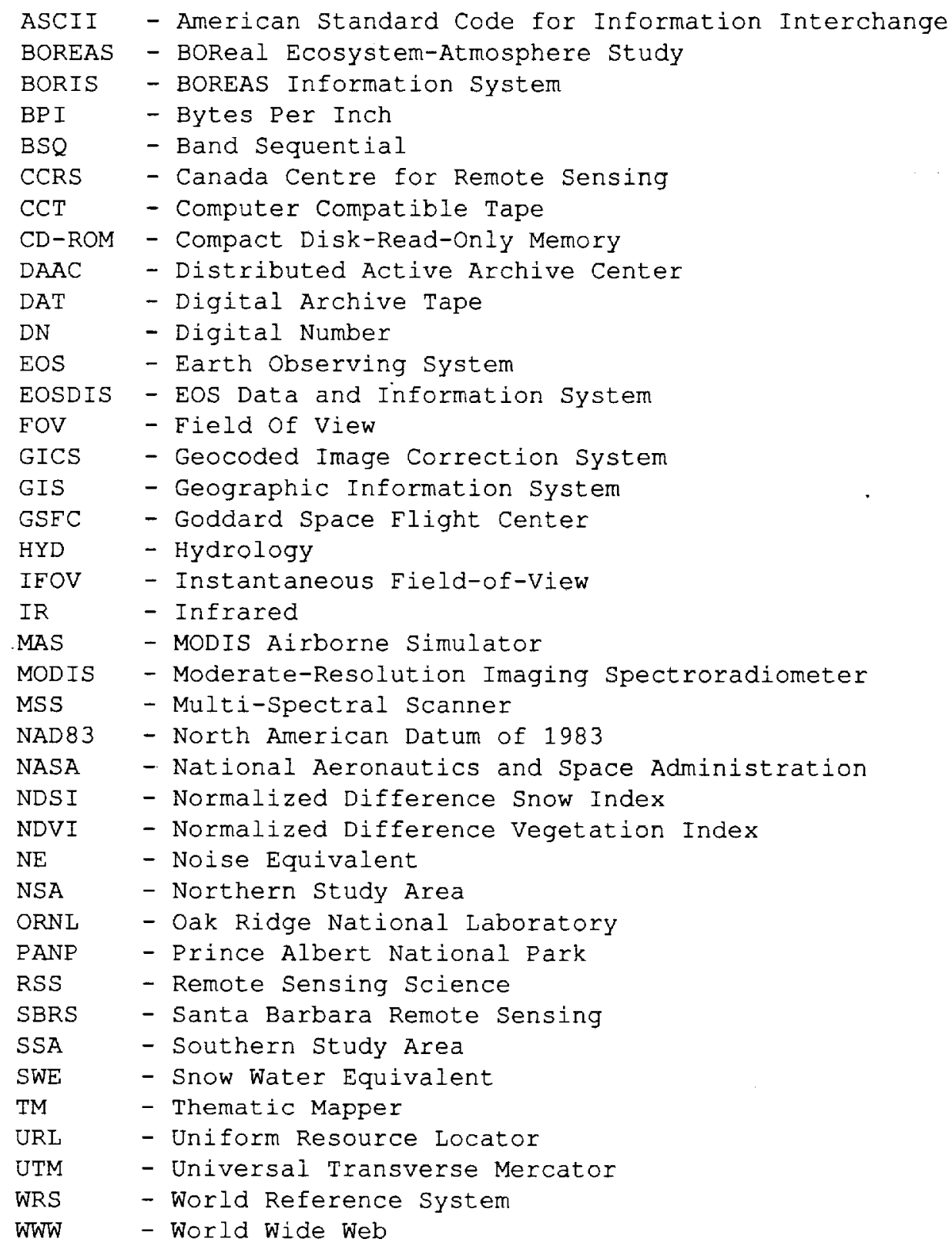

\section{Document Information}

20.1 Document Revision Dates

Written: 15-Dec-1996

Last Updated: 16-Jul-1999

\subsection{Document Review Dates}

BORIS Review: 10-Sep-1997

Science Review: 15-Nov-1997 


\subsection{Document ID}

\subsection{Citation}

If this data set is referenced by another investigator, please acknowledge the paper by Hall et al., 1997, in Section 17.2.

If using data from the BOREAS CD-ROM series, also reference the data as:

Hall, D.K., A.T.C. Chang, and J.L. Foster, "Automated Snow Mapping in the Southern BOREAS Test Site." In Collected Data of The Boreal Ecosystem-Atmosphere Study. Eds. J.

Newcomer, D. Landis, S. Conrad, S. Curd, K. Huemmrich, D. Knapp, A. Morrell, J. Nickeson, A. Papagno, D. Rinker, R. Strub, T. Twine, F. Hall, and P. Sellers. CD-ROM. NASA, 2000.

Also, cite the BOREAS CD-ROM set as:

Newcomer, J., D. Landis, S. Conrad, S. Curd, K. Huemmrich, D. Knapp, A. Morrell, J. Nickeson, A. Papagno, D. Rinker, R. Strub, T. Twine, F. Hall, and P. Sellers, eds. Collected Data of The Boreal Ecosystem-Atmosphere Study. NASA. CD-ROM. NASA, 2000.

\subsection{Document Curator}

\subsection{Document URL}




$$
\text { . }
$$


Public reporting burden for this collection of information is estimated to average 1 hour per response, including the time for reviewing instructions, searching existing data sources, gathering and maintaining the data needed, and completing and revlewing the collection of information. Send comments regarding this burden estimate of any other aspect of this

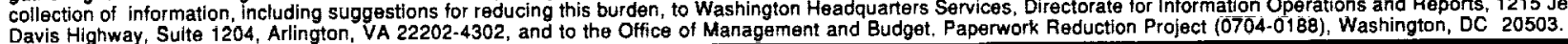

\begin{tabular}{l|l|l}
\hline 1. AGENCY USE ONLY (Leave blank) & 2. REPORT DATE & 3. REPORT TYPE AND DATES COVERED
\end{tabular}

\begin{tabular}{r|r} 
August 2000 & Technical Memorandum
\end{tabular}

4. TITLE AND SUBTITLE

ust 2000 5. FUNDING NUMBERS

Technical Report Series on the Boreal Ecosystem-Atmosphere Study (BOREAS) BOREAS RSS-8 Snow Maps Derived from Landsat TM Imagery

923

6. AUTHOR(S)

Dorothy Hall, Al Chang, Jim Foster, and Janet Y.L. Chien

Forrest G. Hall and Jaime Nickeson, Editors

7. PERFORMING ORGANIZATION NAME(S) AND ADDRESS (ES)

B. PEFORMING ORGANIZATION

REPORT NUMBER

Goddard Space Flight Center

Greenbelt, Maryland 20771

$2000-03136-0$

9. SPONSORING / MONITORING AGENCY NAME(S) AND ADDRESS (ES)

10. SPONSORING / MONITORING AGENCY REPORT NUMBER

National Aeronautics and Space Administration

Washington, DC 20546-0001

TM-2000-209891

Vol. 56

\section{SUPPLEMENTARY NOTES}

J.Y.L. Chien: GSC; J. Nickeson: Raytheon ITSS

12a. DISTRIBUTION/ AVAILABILITY STATEMENT

12b. DISTRIBUTION CODE

Unclassified-Unlimited

Subject Category: 43

Report available from the NASA Center for AeroSpace Information,

7121 Standard Drive, Hanover, MD 21076-1320. (301) 621-0390.

13. ABSTRACT (Maximum 200 words)

The BOREAS RSS- 8 team utilized Landsat TM images to perform mapping of snow extent over the SSA. This data set consists of two Landsat TM images that were used to determine the snow-covered pixels over the BOREAS SSA on 18-Jan-1993 and on 06-Feb-1994. The data are stored in binary image format files.

14. SUBJECT TERMS

BOREAS, remote sensing science, Landsat TM.

15. NUMBER OF PAGES

16. PRICE CODE

17. SECURITY CLASSIFICATION OF REPORT

Unclassified
18. SECURITY CLASSIFICATION OF THIS PAGE

Unclassified
19. SECURITY CLASSIFICATION OF ABSTRACT Unclassified
20. LIMITATION OF ABSTRACT

UL 